\title{
Effect of human-animal relationship and management on udder health in Swiss dairy herds
}

\author{
S. Ivemeyer, ${ }^{\star 1}$ U. Knierim, $†$ and S. Waiblingerł \\ ${ }^{*}$ Animal Health Division, Research Institute of Organic Agriculture (FiBL), Ackerstrasse, 5070 Frick, Switzerland \\ †Department of Farm Animal Behaviour and Husbandry, University of Kassel, Nordbahnhofstraße 1a, 37213 Witzenhausen, Germany \\ łInstitute of Animal Husbandry and Animal Welfare, University of Veterinary Medicine, Veterinärplatz 1, 1210 Vienna, Austria
}

\section{ABSTRACT}

In a cross-sectional study, we investigated the effects of human-animal interactions and management factors on udder health in 46 Swiss dairy herds living in loose-housing systems on farms that participated in the Swiss dairy farm network "pro-Q." The humananimal relationship was measured by observing milkers' behavior, cows' behavior during milking, and cows' avoidance distance in the barn. Management factors were assessed by questionnaire-guided interviews and observations. Udder health was evaluated using indicators that were calculated from milk recording data over a period of $1 \mathrm{yr}$ before assessment: (1) average somatic cell scores (SCS) per herd and (2) incidence of new infections per herd (NEWINF); and indicators that were calculated from quarter milk samples of all lactating cows at the time of assessment: (3) prevalence of quarters with elevated somatic cell counts $(>100,000$ cells/ $\mathrm{mL} ; \% \mathrm{Q}>100)$ and (4) prevalence of mastitis quarters (>100,000 cells/mL and culturally positive; \%Qmast). After univariate preselection of associated factors, multivariable linear regression models were calculated at the herd level and a multilevel regression model was calculated at the herd and cow levels for SCS. Among all of the human-animal relationship factors, the most dominant predictor for SCS, \%Q>100, and \%Qmast was the percentage of positive interactions of milkers with the cows in relation to all of their interactions during milking. Furthermore, a higher prevalence of fearful cows in the herd (with an avoidance distance $>1 \mathrm{~m}$ ) was associated with a higher $\% \mathrm{Q}>100$. In herds with a higher NEWINF, incidents of cows kicking during milking occurred more frequently. Concerning management as well as farm and herd characteristics, the following mastitis risk factors were found: (1) breed, especially Holstein with regard to SCS, NEWINF, and \%Qmast; (2) high age in terms of lactation number with regard to SCS and \%Qmast; (3) high amount of new infec-

Received November 28, 2010.

Accepted July 26, 2011.

${ }^{1}$ Corresponding author: silvia.ivemeyer@fibl.org tions of a cow over 1 yr with regard to SCS; (4) airadsorption during application of teat-cups with regard to NEWINF; (5) lack of separation of diseased cows with regard to NEWINF; and (6) ample dimensions of lying places with regard to \%Qmast. The results suggest that the human-animal relationship is relevant for udder health, especially for cows' reactions to infections expressed as somatic cell count levels. Risk of infection itself appears to be mainly influenced by management factors. Hence, the human-animal relationship may be considered in extension concerning preventive mastitis control.

Key words: human-animal relationship, udder health, dairy herd, management

\section{INTRODUCTION}

Mastitis is one of the most frequent health disorders in dairy cattle, along with fertility disorders, and it causes heavy economic losses (Aeberhardt et al., 1997; Stärk et al., 1997). For the development of successful disease prevention strategies, the well-known multifactorial nature of mastitis (Dohoo and Meek, 1982; Harmon, 1994) needs to be taken into account. Dairy cow breed and a range of management factors (primarily milking hygiene, but also milking technology, housing conditions, feeding, and general herd management) have been identified as influencing mastitis in different studies (Sato et al., 2008; Breen et al., 2009; Ivemeyer et al., 2009). Furthermore, stress was detected as a risk factor for high SCC (Wegner et al., 1976; Dohoo and Meek, 1982). In general, stressed animals were found to be more susceptible to disease (reviewed by De Passillé and Rushen, 1999), and stress (as indicated by metabolic blood values) was found more often in herds with a high incidence of clinical mastitis than in comparable herds with a low incidence of mastitis (Holtenius et al., 2004).

One important influence on the stress level of cows can be the human-animal relationship (De Passillé and Rushen, 1999). The human-animal relationship can be defined as the mutual perception of the animal and the human, which develops and expresses itself in their 
mutual behavior (Waiblinger et al., 2006). Based on previous experiences, animals can perceive humans in a positive way and react with approach behavior. Hemsworth et al. (1989) reported that the stockperson's presence and positive handling during calving of heifers led to faster approach to an experimenter in a test situation, lower cortisol concentrations, and less stepping and kicking during milking in the first weeks of lactation. On the other hand, animals can associate humans with negative experiences and show reactions of fear and stress. For example, negative handling of heifers resulted in greater flight distances and higher cortisol concentrations, indicating acute stress (Breuer et al., 2003). Hence, the behavior of the stockperson can not only cause, but also reduce stress in animals. This was confirmed by Waiblinger et al. (2004), who showed that stress could be reduced through positive handling by a familiar person during veterinarian rectal palpation. Furthermore, positive handling can be remembered by cows and has a long-term effect on cows' behavior toward humans and on stress reactions during veterinary procedures (Waiblinger et al., 2004; Schmied et al., 2008, 2010). The human-animal relationship has also been associated with milk yield, residual milk, and health of dairy cattle (Knierim and Waran, 1994; Hemsworth et al., 2000; Waiblinger et al., 2002).

The human-animal relationship can be assessed by observing the behavior of the animals and the human handler. From the animal's perspective (i.e., the animal's perception of humans), the relationship can be evaluated through standardized tests such as the avoidance distance test. This established, reliable, and validated on-farm test measures the reactions of dairy cows to a moving human (Waiblinger et al., 2003, 2006; Windschnurer et al., 2008). A further measure may be the behavior of dairy cows during milking (stepping, kicking) as a response to actual human handling (Waiblinger et al., 2006). In several studies, the behavior of cows during milking has been found to be related to human handling and behavior, and to the level of fear cows have of humans (Rushen et al., 1999; Munksgaard et al., 2001; Waiblinger et al., 2002). The stockperson's behavior has often been measured in terms of tactile and acoustic interactions during routine handling situations such as milking. These interactions were counted and categorized as being positive or negative and, in some studies, as neutral interactions (Breuer et al., 2000; Hemsworth et al., 2000; Waiblinger et al., 2002).

In mastitis research, the human-animal relationship has not yet received much attention as a potential risk factor. From a study of 66 dairy farms in Australia, Hemsworth et al. (2000) reported on significant positive correlations between the number of negative tactile interactions by the milkers and the bulk milk SCC, al- though apparently no subsequent multivariable regression analysis was carried out on SCC as a dependent variable.

The aim of this epidemiological study on Swiss dairy farms was to evaluate the relative importance of the quality of human-animal relationship with regard to udder health while taking into account risk factors related to herd characteristics and management.

\section{MATERIALS AND METHODS}

\section{Farms}

In total, 46 farms from the Swiss dairy farm network "pro-Q" (Ivemeyer et al., 2008) were investigated between April 2005 and September 2007. All farms had loose-housing systems and milking parlors. Only farms with 3 or fewer regular milkers and with monthly milk recording data that included composite cow SCC (CSCC) from at least $1 \mathrm{yr}$ before the start of the project were included in the study. At the time of data assessment, all investigated farms had participated for at least $1 \mathrm{yr}$ in the voluntary pro-Q extension program that is concerned with udder health. To avoid observation influence on milkers' behavior, the farmers only knew in general about the investigation into the effects of milking procedures and milking management on mastitis risk. After the observations, they were told about the additional investigation of the human-animal relationship, and thus observations of milker behavior, and were then asked for their consent for the data to be used.

\section{Data Collection}

All observations and measurements (except the CSCC data) took place during 1 of (up to) 4 farm visits. Quarter milk samples of all lactating cows were collected during one milking. Within a timeframe of $1 \mathrm{~d}$ to 5 wk (mean of $3 \mathrm{~d}$ ), observations were performed during milking (depending on the number of regular milkers and their working periods). One complete milking was observed for each regular milker of a herd (maximum of 3 milkers). During milking, the tactile and acoustic behavior of the milkers toward the cows, the milking management, and the stepping and kicking behaviors of the cows were recorded using the software Pocket Observer (version 2.0, Noldus Information Technology, Wageningen, the Netherlands) on a hand-held device (Pocket PC h2210, Hewlett Packard, Palo Alto, CA). Avoidance distances (AD) of the cows were tested in the barn on the same day that the first milking observations had taken place. After all observations had been recorded, the farmer was asked about his or her herd 
management using a standardized questionnaire. The farm visits were spread over the whole year, but most of them took place during winter. All observations and avoidance tests were conducted by the same person.

\section{Herd, Housing, and Management Factors}

The selection of the 34 environmental factors that were included in the study as further udder health risk factors was based on theoretical considerations and on results from previous studies (Waiblinger et al., 2002; Ivemeyer et al., 2009). These factors were general farm and herd issues (such as farm location and herd breed), herd management, housing in terms of lying place, milking management (concerning hygiene and processes), and milking technology. The different factors, categories, and the frequencies of their occurrence are shown in Table 1. Average daily milk yield (DMY) and lactation number $(\mathbf{L N})$ per herd were calculated from milk recording data collected during the year before the investigation. Information about the agricultural zone and the workforces on the farms was obtained from the Swiss Federal Statistical Office (BFS, Neuchâtel). The other data were collected via questionnaire-guided interviews of the farmers or by direct assessments during farm visits. All assessments were done by the same person, except for the evaluations of functional properties of the milking technology, which was done by one external expert on all farms.

\section{Stockperson Behavior}

Acoustic and tactile interactions of milkers with cows were recorded and categorized in the milking parlors according to the methods described in Waiblinger et al. (2002). Single predefined interactions of each milker were counted. Interactions with durations longer than $1 \mathrm{~s}$ were counted as a new event every second. The single interactions were grouped as positive interactions (POS) per milked cow, neutral interactions (NEUT) per milked cow, negative interactions (NEG) per milked cow, and noise per milked cow (NOISE; Waiblinger et al., 2002; Table 2). The percentages of the use of positive, neutral, negative, and noise interactions in relation to the total number of interactions during the milking observation were calculated (POS\%, NEUT\%, NEG\%, and NOISE\%). If a farm had more than one observed regular milker, the data were summarized at the farm level. For this purpose, the data of the milkers were weighted according to their milking frequency and their degree of influence on herd management; that is, farm managers and long-term employees were weighted with factor of 1 , apprentices with factor of 0.7 , and family members milking from time to time with factor of 0.5. Stockperson behavior observations were thus summarized as a single observation per herd.

\section{Cow Behavior}

During milking, each step [defined as weight displacement with slight $(\leq 15 \mathrm{~cm})$ elevation of foot] and each kick [defined as a distinct raising of the foot $(>15 \mathrm{~cm})$; Rushen et al., 1999] were recorded when the milker was working with the cow or was just standing nearby (within $0.5 \mathrm{~m}$; Waiblinger et al., 2002). The variables STEP and KICK express the number of these behaviors per milked cow. If a farm had more than one observed regular milker, the cow behavior data of the several milking recordings were summarized on the farm level, as described above for stockperson behavior.

Avoidance distances were assessed in the barn or in an outside yard according to the method described by Waiblinger et al. (2002) and Windschnurer et al. (2008). Individual freestanding animals were approached from the front by the researcher, who was always wearing a green overall. Starting at a distance of $3 \mathrm{~m}$, the researcher approached the cow at a speed of 1 step per second with one arm held at $45^{\circ}$ in front of the body. The distance between the researcher's hand and the cow's nose was estimated, in steps of $0.1 \mathrm{~m}$, at the moment of the cow's withdrawal. In cases when the cow remained standing until touched, the researcher tried to stroke her head. If an animal withdrew immediately at the moment of touching, an $\mathrm{AD}$ of $0.001 \mathrm{~m}$ was assigned. If the cow allowed herself to be stroked, the $\mathrm{AD}$ was $0 \mathrm{~m}$. In each herd, the $\mathrm{AD}$ test was carried out with at least $75 \%$ of the animals, with up to 3 repeated measures per cow. In a first step, the average distance per cow was calculated. Afterward, the median of the $\mathrm{AD}$ of all cows (MeAD), the percentage of cows with an $\mathrm{AD}$ of zero $(\leq 0.05 \mathrm{~m}, \mathbf{\%} \mathbf{A D 0})$, and the percentage of cows with an $\mathrm{AD}$ greater than $1 \mathrm{~m}(\boldsymbol{\%} \mathbf{A D}>\mathbf{1})$ was calculated for each herd.

\section{Udder Health}

Milk recording data, including CSCC from the year before the start of this study (11 measurements), were available from all investigated farms. Based on milk recording data, 2 long-term variables over 1 yr were calculated. The first variable was the average SCS of the herd over the year. To obtain normally distributed SCS data, all CSCC were transformed using the formula $\mathrm{SCS}=\log _{2}(\mathrm{CSCC} / 100,000)+3$ (Wiggans and Shook, 1987). Then, the average SCS of the herd over 1 yr was calculated. Measurements within the first $5 \mathrm{~d}$ of lactation were excluded (Dohoo, 1993). The second variable based on the milk recording data was the new infection 
Table 1. Characterization of visited farms $(n=46)$ regarding 34 factors potentially influencing udder health, with number of farms per category or means and standard deviations (SD) over all farms

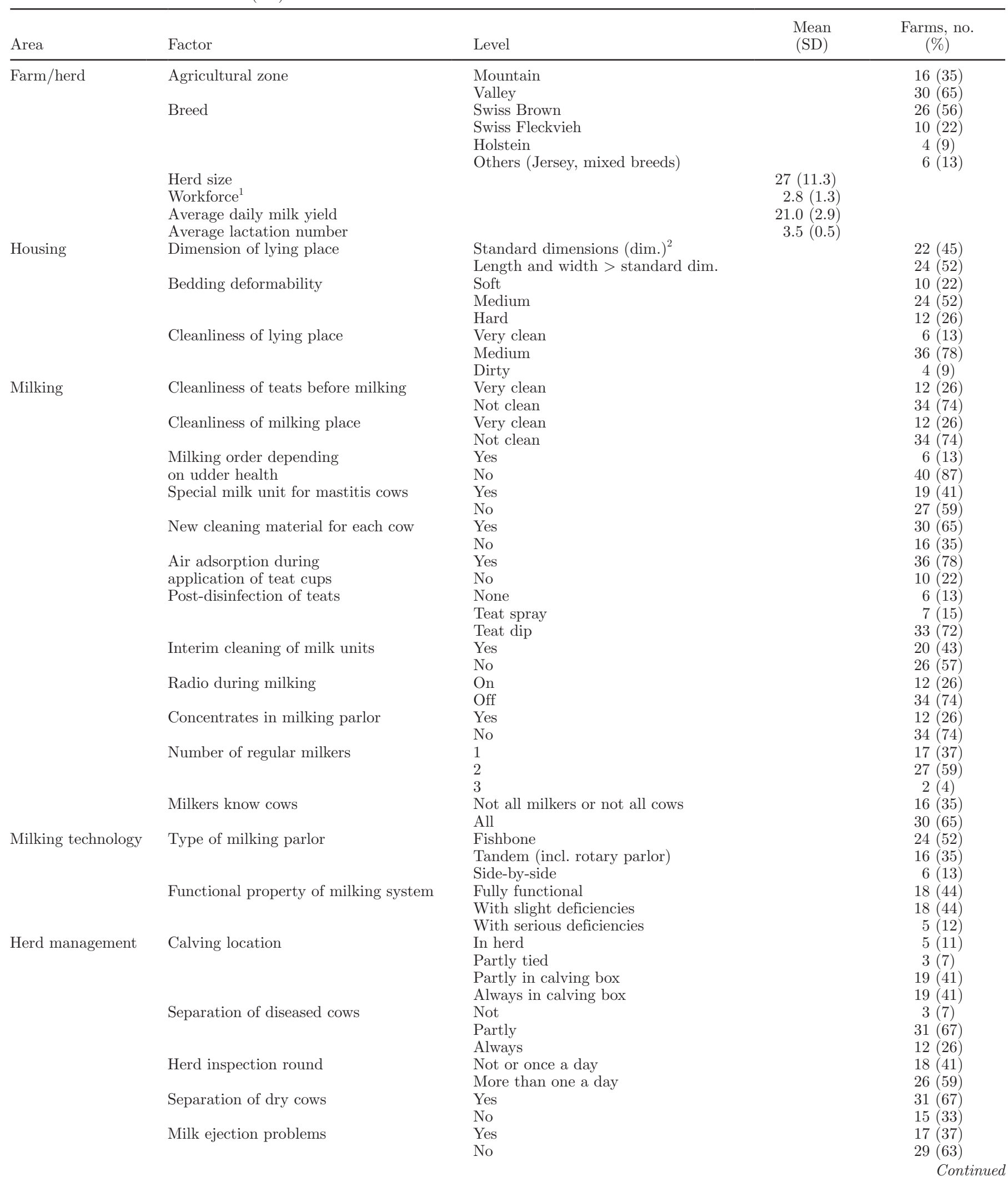


Table 1 (Continued). Characterization of visited farms $(n=46)$ regarding 34 factors potentially influencing udder health, with number of farms per category or means and standard deviations (SD) over all farms

\begin{tabular}{|c|c|c|c|c|}
\hline Area & Factor & Level & $\begin{array}{c}\text { Mean } \\
(\mathrm{SD})\end{array}$ & $\begin{array}{l}\text { Farms, no. } \\
\quad(\%)\end{array}$ \\
\hline & \multirow[t]{2}{*}{ Breeding selection on goodnaturedness } & Yes & & $10(22)$ \\
\hline & & No & & $36(78)$ \\
\hline & Breeding selection on manageability & No & & $33(72)$ \\
\hline & \multirow{2}{*}{$\begin{array}{l}\text { Point in time of separation of } \\
\text { cow and calf postpartum }\end{array}$} & $<1 \mathrm{~h}$ & & $13(28)$ \\
\hline & & $>1 \mathrm{~h}$ to $\leq 24 \mathrm{~h}$ & & $18(39)$ \\
\hline & $\begin{array}{l}\text { Point in time of integration of } \\
\text { heifers in the herd prepartum }\end{array}$ & $>4$ wk prepartum & & $6(13)$ \\
\hline & Active familiarization of heifers & Yes & & $26(57)$ \\
\hline & to milking parlor prepartum & No & & $20(43)$ \\
\hline & Familiarization of heifers to & Yes & & $38(83)$ \\
\hline & human contact prepartum & No & & $8(17)$ \\
\hline
\end{tabular}

${ }^{1}$ Standardized workforce according to Swiss Federal Statistical Office (BFS).

${ }^{2}$ In line with standard dimensions according to Swiss Animal Welfare Regulations.

rate (NEWINF), according to the method described by Valde et al. (2005). It was calculated by counting all new infections per 100 recordings, defined as conversions of CSCC for each cow, that cross a threshold of 200,000 cells/mL in subsequent measurements.

The percentage of quarters with elevated SCC (>100,000 cells/mL; \%Q $>\mathbf{1 0 0}$ ) and the percentage of mastitis quarters (\%Qmast) were calculated based on quarter milk samples of the lactating herd at the time of assessment, which were taken aseptically before milking. Mastitis quarters were defined as SCC $>100,000$ cells $/ \mathrm{mL}$ and culture positive (except for contamination with more than 2 species), according to the Deutsche Veterinärmedizinische Gesellschaft/International Dairy Federation (DVG/IDF) mastitis definition (DVG, 2002). The milk samples were analyzed by a certified commercial veterinary laboratory in Switzerland.

\section{Statistical Analyses}

All metric data concerning the human-animal relationship showed graphically (normal quantile-quantile plots; Hüsler and Zimmermann, 2006) that they were not normally distributed, whereas udder health variables were evaluated as being normally distributed.
Preselection of factors for the multivariable regression modeling was carried out using univariate analyses: Spearman rank correlations $\left(\mathbf{r}_{\mathrm{s}}\right)$ in the case of metric independent variables and ANOVA for categorical independent variables and normally distributed dependent variables. All factors with $P \leq 0.10$ were used for the multiple independent variable regression models. However, variables with strong correlations $\left(\mathrm{r}_{\mathrm{s}}>0.70\right)$ or similar contents were not included in the same model to avoid multicollinearity. In those cases, the independent variable with the highest correlation to the dependent variable $\left(r_{s}\right)$ was chosen. Linear regression models with stepwise backward elimination of factors not significantly associated with the dependent variable (threshold for elimination: $P=0.05$ ) were calculated for effects on the 4 udder health variables at herd level. The amount of variance explained through the independent variables was described through the adjusted coefficient of determination $\left(\mathrm{R}^{2}\right.$ adj). Model diagnostics were done by graphical evaluation of the residual distribution and the residual by predicted values plot. Multicollinearity was checked by the variance inflation factor (VIF) value. The level of significance used was $\alpha$ $=0.05$, and the results are referred to as tendencies in case of $0.05<\alpha \leq 0.10$.

Table 2. Scheme of grouping observed milkers' tactile and acoustic interactions into positive, neutral, negative, and noise interactions (method and definition of single interactions are described in Waiblinger et al., 2002)

\begin{tabular}{ll}
\hline $\begin{array}{l}\text { Interaction } \\
\text { group }\end{array}$ & Summarized single interactions \\
\hline Positive & Talking quietly, petting, touching \\
Neutral & Talking dominantly, hand gentle, stick gentle \\
Negative & Talking impatiently, shouting, hand forceful, stick forceful \\
Noise & Clapping, whistling, knocking on equipment with a stick \\
\hline
\end{tabular}


Table 3. Median and range (minimum and maximum) of stockperson and cow behavior

\begin{tabular}{|c|c|c|c|}
\hline Variable & Median & Minimum & Maximum \\
\hline \multicolumn{4}{|l|}{ Stockpersons' behavior ( $\mathrm{n}=73$ milkers $)$} \\
\hline Positive interactions/milked cow, no. & 1.50 & 0.20 & 12.40 \\
\hline Neutral interactions/milked cow, no. & 1.94 & 0.09 & 8.35 \\
\hline Negative interactions/milked cow, no. & 0.08 & 0 & 1.89 \\
\hline Noise interactions/milked cow, no. & 0.06 & 0 & 2.72 \\
\hline Positive interactions, $\%$ of all interactions & 38.7 & 4.8 & 75.0 \\
\hline Neutral interactions, $\%$ of all interactions & 49.3 & 19.7 & 80.9 \\
\hline Negative interactions, $\%$ of all interactions & 1.8 & 0 & 21.4 \\
\hline Noise interactions, $\%$ of all interactions & 1.3 & 0 & 40.2 \\
\hline \multicolumn{4}{|l|}{ Cows' behavior $(\mathrm{n}=46$ herds) } \\
\hline Median of avoidance distance (AD) & 0.26 & 0 & 1.23 \\
\hline Cows with $\mathrm{AD}$ of $0 \mathrm{~m}$ in herd, $\%$ & 28.29 & 0 & 64.29 \\
\hline Cows with $\mathrm{AD}>1 \mathrm{~m}$ in herd, $\%$ & 19.52 & 0 & 62.96 \\
\hline Kicking of cows/milked cow & 0.19 & 0 & 2.57 \\
\hline Stepping of cows/milked cow & 0.95 & 0.11 & 3.48 \\
\hline
\end{tabular}

Because it was not possible to calculate a valid model at the herd level for SCS and because individual cow data were available, a multilevel regression model according to Goldstein (1995) was used to analyze SCS as the outcome variable with independent variables at cow and herd levels. The model was

$$
\mathrm{SCS}_{i j}=\beta_{0 i j}+u_{0 j}+\beta_{1} \mathrm{x}_{1 i j}+\beta_{2} \mathrm{x}_{2 i j}+\ldots+\beta_{\mathrm{n}} \mathrm{x}_{\mathrm{n} i j}+e_{0 i j} \text {, }
$$

where $\operatorname{SCS}_{i j}$ represents the SCS of the cow $i$ in herd $j$, $\beta_{0 i j}$ is the intercept, $u_{0 j}$ is the residual variance at level $j$ (herd), $\beta_{1} \mathrm{x}_{1}$ is the fixed effect of the first variable $\mathrm{x}_{1}, \beta_{2} \mathrm{x}_{2 i j}$ is the fixed effect of the second variable $\mathrm{x}_{2}$, $\beta_{\mathrm{n}} \mathrm{x}_{\mathrm{n} i j}$ is the fixed effect of the nth variable $\mathrm{x}_{\mathrm{n}}$, and $e_{0 i j}$ represents the residual variance at level $i$ (cow). In this model, breed, number of new infections (NNEWINF), LN, and DMY were included as factors at the cow level. Initially a null model was fitted to estimate the variance of the residuals on the 2 levels. In the next step, a random intercept model was fitted using the iterated generalized least squares algorithm, including all factors that were associated with the SCS in the univariate analyses at $P \leq 0.10$. None of them was strongly correlated with each other. Additionally, variables were included on grounds of plausibility, with $P>0.10$ at the herd level, to improve the model fit. The model was reduced manually by backward elimination of nonsignificant factors. Only significant factors were kept in the final model. Residuals in the multilevel analysis were also evaluated graphically.

The multilevel analysis was calculated with MLwiN 1.1 software (Centre for Multilevel Modeling, University of Bristol, United Kingdom). All other statistical analyses were carried out using SPSS 13.0 software (SPSS Inc., Chicago, IL).

\section{RESULTS \\ Descriptive Statistics of Herds}

The mean herd size of the 46 investigated dairy farms was $27 \pm 11.3$ cows (range: 10 to 58). All farms were located in Switzerland, except for one that was located in south Germany near the border with Switzerland. The majority of the farms had Swiss Brown herds (SB), Swiss Fleckvieh herds (SF), or HolsteinFriesian (HF) herds (Table 1). In detail, 145 HF cows, 140 Red Holstein (RH) cows, 549 Brown Swiss (BS, as main segment of Swiss Brown) cows, 106 SF cows, 30 Jersey (JE) cows, 18 Original Swiss Brown (OB) cows, and 110 cows of other breeds (crossbreeds, Grey cattle, Hinterwälder cattle; $\mathbf{X X}$ ) were included in the project. Most of the herds were from certified organic farms $(93.5 \%, \mathrm{n}=43)$, whereas the remainder $(\mathrm{n}=3)$ practiced integrated production (a certified conventional farming standard in Switzerland). On all included farms, cows were housed in loose-housing systems with a permanent winter outside run and access to pasture in summer. Most farms had a cubicle housing system, 1 farm had a strawyard system, and 4 farms had a mixture of cubicles and strawyard system. More characteristics concerning farms, herd, housing, and management are shown in Table 1.

The mean SCS over 1 yr for all farms was 2.85 ( \pm 0.44 ; equivalent to 90,130 cells $/ \mathrm{mL}$ ). The NEWINF in that year amounted to $8.93 \%( \pm 2.99)$. The average $\% \mathrm{Q}>100$ based on quarter milk samples of all lactating cows was $29.62 \%( \pm 12.08)$, and the average \%Qmast was $16.86 \%( \pm 8.20)$.

The observed behavior characteristics of stockpersons and cows in the herds are listed in Table 3. The most frequently observed milker behaviors were NEUT 
Table 4. Results of univariate analyses for preselection of independent factors in subsequent regression models: correlation coefficients (Spearman rank test, $\mathrm{r}_{\mathrm{s}}$ ) or group means (ANOVA, if $\left.P<0.10\right)$ for factors showing associations $(P<0.10)$ with at least one of the udder health variables ${ }^{1}$; factors in bold were included in the subsequent regression modeling

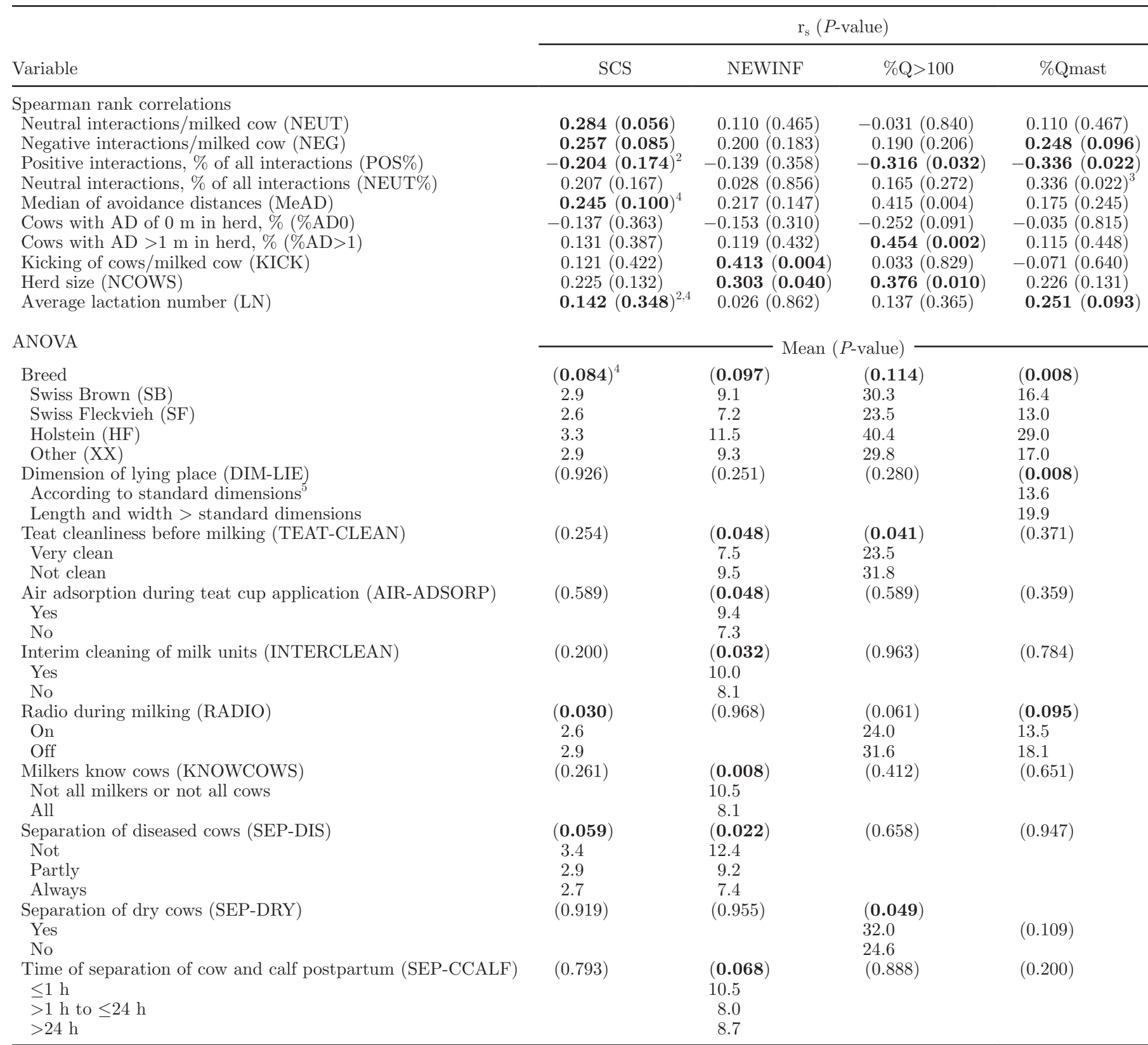

${ }^{1} \mathrm{NEWINF}=$ new infection incidence; $\% \mathrm{Q}>100=$ prevalence of quarters with elevated cell counts; \%Qmast = prevalence of mastitis quarters.

${ }^{2}$ These variables were included in the multilevel-model to improve model fit (even though $P>0.10$ ).

${ }^{3}$ These variables were not included in the regression model to improve final model fit after backward selection.

${ }^{4}$ These variables were included on the cow level in the multilevel model, but data in this table are on the farm level.

${ }^{5}$ Standard dimensions according to Swiss Animal Welfare Regulations.

and POS with a median of 1.94 and 1.50 interactions per milked cow, respectively. Negative interactions accounted for only $1.8 \%$ of all interactions with a median of 0.08 interactions per milked cow, and the MeAD was $0.26 \mathrm{~m}$. Behavior of stockpersons and cows varied markedly among farms.

\section{Multivariable Analyses of Effects on Udder Health}

Preselection results are presented in Table 4. The variables integrated in the multivariable analyses are marked in bold. In the multivariable linear regression model with NEWINF as the dependent variable, the fol- 
Table 5. Final linear regression model regarding herd new infection incidences over $1 \mathrm{yr}$ (NEWINF: $\mathrm{R}^{2}=0.460, \mathrm{R}^{2}$ adjusted $=0.407, F$ $=8.724, P<0.001 ;$ variance inflation factor $=1.016-1.094 ; \mathrm{n}=46)$

\begin{tabular}{lrrrr}
\hline Variable $^{1}$ & Estimate & $\mathrm{SE}$ & \multicolumn{1}{c}{$t$} & $P$-value \\
\hline Intercept & 12.457 & 1.476 & 8.440 & $<0.001$ \\
KICK & 2.548 & 0.761 & 3.347 & 0.002 \\
AIR-ADSORP & 2.175 & 0.831 & -2.619 & 0.012 \\
SEP-DIS & -1.615 & 0.663 & -2.437 & 0.019 \\
Breed HF & 2.811 & 1.221 & 2.302 & 0.026 \\
\hline
\end{tabular}

${ }^{1} \mathrm{KICK}=$ kicking of cows during milking/milked cow; AIR-ADSORP $=$ air adsorption during teat cup application; SEP-DIS $=$ separation of diseased cows; $\mathrm{HF}=$ Holstein-Friesian.

lowing factors were significant: breed HF, KICK, separation of diseased cows (SEP-DIS), and air adsorption during application of teat cups (AIR-ADSORP; Table 5). Regarding $\% \mathrm{Q}>100$ as the dependent variable, the 2 human-animal relationship-based factors $\% \mathrm{AD}>1$ and $\mathrm{POS} \%$ remained as significant predictors in the model (Table 6). The factors LN, breed HF, dimension of lying space (DIM-LIE), and POS\% remained significant in the model with regard to \%Qmast in the herd (Table 7).

In the multilevel linear regression model, regarding SCS as the dependent variable, data from 1,098 cows (level $i$ ) from 46 herds (level $j$ ) were included. The null model (2-level null random intercept) showed that $91.8 \%$ of variance of SCS was determined by differences between cows $\left[e_{0 i j} /\left(u_{0 j}+e_{0 i j}\right) \times 100\right]$, whereas $8.2 \%$ of the variance was determined by differences between herds $\left[u_{0 j} /\left(u_{0 j}+e_{0 i j}\right) \times 100\right]$. The variance was significant at both cow and herd levels. Thus, differences in SCS between and within the herds existed. The average SCS at the cow level was 2.708 . The residual variance of SCS in the final random intercept model resulted from both the differences between herds $\left(u_{0 j}=0.039\right.$; $P=0.029)$ and between cows $\left(e_{0 i j}=1.066 ; P<0.001\right)$. The model explained $71.5 \%$ of the variance at the herd level $\left(\mathrm{R}_{\text {herd-level }}^{2}\right)$. The coefficient of determination at the cow level amounted to $33.8 \%\left(\mathrm{R}_{\text {cow-level }}^{2}\right)$. The following factors remained significant in the final random intercept model for cow differences: LN, NNEWINF, and DMY. The breeds FV, JE, OB, and XX had a signifi-

Table 6. Final linear regression model regarding herd prevalence of quarters with elevated cell counts $\left(\% \mathrm{Q}>100 ; \mathrm{R}^{2}=0.228, \mathrm{R}^{2}\right.$ adjusted $=0.192, F=6.341, P=0.004 ;$ variance inflation factor $=1.008 ; \mathrm{n}$ $=46)$

\begin{tabular}{lrrrr}
\hline Variable $^{1}$ & Estimate & $\mathrm{SE}$ & \multicolumn{1}{c}{$t$} & $P$-value \\
\hline Intercept & 34.296 & 5.565 & 6.163 & $<0.001$ \\
$\% \mathrm{AD}>1$ & 0.264 & 0.103 & 2.557 & 0.014 \\
POS\% & -0.258 & 0.115 & -2.244 & 0.030 \\
\hline
\end{tabular}

${ }_{1} \% \mathrm{AD}>1=\%$ cows with avoidance distance $>1 \mathrm{~m} ;$ POS $\%=\%$ positive interactions of all interactions.
Table 7. Final linear regression model regarding herd prevalence of mastitis quarters (\%Qmast) $\left(\mathrm{R}^{2}=0.575, \mathrm{R}^{2}\right.$ adjusted $=0.533, F=$ $13.849, P<0.001 ;$ variance inflation factor $=1.050-1.078 ; \mathrm{n}=46$ )

\begin{tabular}{lrccr}
\hline Variable $^{1}$ & Estimate & SE & $t$ & $P$-value \\
\hline Intercept & 2.527 & 7.033 & 0.359 & 0.721 \\
Breed HF & 15.845 & 3.005 & 5.272 & $<0.001$ \\
DIM-LIE & 6.943 & 1.695 & 4.097 & $<0.001$ \\
LN & 4.216 & 1.736 & 2.428 & 0.020 \\
POS\% & -0.133 & 0.061 & -2.203 & 0.033 \\
\hline
\end{tabular}

${ }^{1} \mathrm{HF}=$ Holstein-Friesian; DIM-LIE $=$ dimension of lying space; LN $=$ average lactation number; $\operatorname{POS} \%=\%$ positive interactions of all interactions.

cantly lower SCS than HF, whereas RH and BS breeds showed no significant SCS difference from HF. At the herd level, the factors POS\% and the factor radio on during milking (RADIO) were significant (Table 8).

\section{DISCUSSION}

The current study was performed to investigate the potential effect of the human-animal relationship on udder health while taking herd and management factors into account. Regarding udder health, the investigated herds had a slightly higher mean SCS than Swiss dairy farms in general (project farms: SCS 2.85; 1,674 randomly selected Swiss farms: SCS 2.69). This may be due to the preselection of farms participating voluntarily in an udder health extension project. The results of the regression models indicate that the human-animal relationship on the farm is directly associated with udder health in dairy cows through the behavior of stockpersons toward the cows and the cows'

Table 8. Final multilevel linear regression model regarding SCS $\left(\mathrm{R}_{\text {herd level }}^{2}=0.715, \mathrm{R}_{\text {cow level }}^{2}=0.338 ; \mathrm{n}=1,098\right.$ cows in 46 herds $)$

\begin{tabular}{lcccr}
\hline Variable $^{1}$ & Level & Estimate & SE & $P$-value \\
\hline Intercept & & 3.116 & 0.252 & $<0.001$ \\
LN & Cow & 0.166 & 0.015 & $<0.001$ \\
NNEWINF & Cow & 0.678 & 0.045 & $<0.001$ \\
Breed & Cow & & & \\
HF & & Reference & & \\
RH & & -0.212 & 0.157 & 0.178 \\
SF & & -0.457 & 0.159 & 0.004 \\
JE & & -0.598 & 0.279 & 0.032 \\
BS & & -0.181 & 0.129 & 0.160 \\
OB & & -0.666 & 0.286 & 0.020 \\
XX & Cow & -0.038 & 0.154 & 0.012 \\
DMY & Herd & -0.009 & 0.008 & $<0.001$ \\
POS\% & Herd & -0.317 & 0.003 & 0.010 \\
Radio on & & 0.107 & 0.003 \\
\hline
\end{tabular}

${ }^{1} \mathrm{LN}=$ average lactation number; NNEWINF $=$ number of new infections: $\mathrm{HF}=$ Holstein-Friesian; $\mathrm{RH}=$ Red Holstein: $\mathrm{SF}=$ Swiss Fleckvieh; JE $=$ Jersey; $\mathrm{BS}=$ Brown Swiss; $\mathrm{OB}=$ Original Swiss Brown; $\mathrm{XX}=$ crossbreeds and other breeds; $\mathrm{DMY}=$ daily milk yield; $\operatorname{POS} \%=\%$ positive interactions of all interactions; Radio on $=$ radio on during milking. 
subsequent level of fear and behavioral and physiological stress reactions. In 3 of the 4 udder health variables, the percentage of positive interactions used by the milkers (POS\%) was associated with improved udder health (lower \%Q>100, \%Qmast, and SCS). Additionally, on farms with a higher percentage of cows with a high level of fear of humans (i.e., cows having an $\% \mathrm{AD}>1 \mathrm{~m})$, the percentage of quarters with elevated SCC $(\% \mathrm{Q}>100)$ was higher. Finally, a higher NEWINF was found on farms with higher frequency of incidents of cows kicking during milking. Apart from $\% \mathrm{Q}>100$, where $\mathrm{POS} \%$ and $\% \mathrm{AD}>1 \mathrm{~m}$ were the only predicting variables included in the regression model, further risk factors from the areas of management, housing, and cow characteristics were identified.

\section{Effect of the Human-Animal Relationship on Udder Health}

Overall, in the area of human-animal relationships, the percentage of positive interactions used by stockpeople during milking (POS\%) was the factor with the strongest association with udder health. It showed a correlation that can be interpreted as a reducing effect on the SCC-based variables SCS, \%Q>100, and \%Qmast, but not on the longer term NEWINF. New infections are probably caused predominantly by conditions such as insufficient hygiene, which enables pathogens to invade the udder. However, a cow's reaction to the infection will affect the progress and duration of mastitis and thereby the longer term SCS, as well as average rates of quarters with increased cell counts or mastitis that were estimated by $\% \mathrm{Q}>100$ and $\%$ Qmast. Cows with a strong immune system and a more intensive immune response (e.g., regarding phagocytosis) have shown higher mastitis cure rates (Hamann, 2008). Hence, cows with better immune function will cope with an infection in a way that it will not become chronic and SCC will decrease. Additionally, stress may increase the magnitude of the immediate SCC response to infection, as was found by Reneau (1986) and Walkenhorst et al. (2005).

Positive interactions reduce the fear of humans and stress in dairy cows, both in the long term and in the short term (Rushen et al., 2001; Waiblinger et al., 2004; Schmied et al., 2008). Therefore, positive behavior by stockpersons may have beneficial effects on udder health by reducing the stress of cows during human-animal interactions, leading to a better immune function (Gross and Siegel, 1982; Barnett et al., 1994; Moberg, 2000). Our results confirm findings from earlier studies of more positive behavior or attitudes and fewer negative behavior or attitudes being associated with lower SCC (Hemsworth et al., 2000; Mülleder and Waiblinger, 2004).

If more cows on the farms were noticeably fearful of humans (higher \%AD>1), \%Q>100 was also higher. Cows with a fear of humans that are in situations of close contact with humans while having no control (in the sense of being able to avoid humans, such as in the milking parlor) can experience physiological stress reactions (Breuer et al., 2003) and stress can lead to higher SCC (Dohoo and Meek, 1982). This will be affected by both the general level of fear of humans and the actual behavior of the stockperson during milking, which can result in a perception of milking as more or less unpleasant and thus stressful (Waiblinger et al., 2006). Rushen et al. (2001) found more stepping, higher heart rates, and more residual milk in cows in the presence of a person during milking who had previously handled them aversively. Cortisol in milk was reduced in heifers after positive handling, which indicates that lower levels of fear were experienced (Hemsworth et al., 1989). In line with these reported relationships between stockperson behavior and fear and stress responses in cows, our results of increased cell counts may be explained via this physiological mechanism.

On the other hand, one may think of the direction of association being the opposite, with a higher mastitis rate leading to more cows with higher $\mathrm{AD}$ due to cows with mastitis associating painful milking with humans. However, the level of pain depends on the severity of symptoms in clinical cases (Milne et al., 2005) and it is unlikely that subclinical mastitis is painful. Thus, for the individual cow, time with pain due to mastitis is low compared with the daily handling experience and thus this experience seems unlikely to have a lasting influence on $\mathrm{AD}$.

The use of a high percentage of positive interactions may reduce stress during milking and thus avoid negative effects of stress on the immune system. In addition, stress may be reduced by the physiological effects of positive tactile stimulation, which may activate the "antistress system," thereby directly supporting cows' immune functions and self-healing, and leading to lower SCC and lower mastitis prevalence (Uvnäs-Moberg et al., 2001; Caroprese et al., 2006). Thus, the relevance of interactions during milking may go beyond the general effects of cows' experiences with humans.

As mentioned above, the lack of association between the rate of new infections and milker behavior suggests that physiological stress reactions and immune function have relatively low relevance for NEWINF. However, the frequency of kicking, which may be a behavioral sign of higher level of fear of humans (Hemsworth et al., 1989; Munksgaard et al., 2001), was identified as risk 
factor. One explanation could be the risk of infections when the milking unit had fallen to the floor after a cow's kick so that air and dirt became adsorbed. This notion is supported by the inclusion of the risk factor AIR-ADSORP as a predictor of NEWINF, which can be led back to re-spray effects from infected milk into healthy quarters. Chassagne et al. (2005) also found this to be a risk factor for high herd SCC. Whereas kicking may be associated with pain in cows during mastitis, this is unlikely to be the explanation for inclusion into the model of NEWINF, as KICK was observed as a short-time variable at one point of time at the end of the project year, whereas NEWINF was calculated as a long-term variable based on milk recording data over the year. Thus, NEWINF does not directly reflect the number of cows having mastitis during observations for KICK.

\section{Herd, Housing, and Management Risk Factors}

Breed was a predictor variable in all mastitis indicator variables except $\% \mathrm{Q}>100$. The higher NEWINF of $\mathrm{HF}$ cows might be caused by reduced robustness against infections of the udder; for example, because of the insufficient teat canal barrier of Holstein cows (Senft and Neudecker, 1991) due to intensive selection for milk yield, short teats, and quick milk flow. In addition, \%Qmast and SCS were higher in Holstein cows, which confirms previous studies that have shown more mastitis problems in Holstein cattle than in other breeds (Busato et al., 2000; Roesch et al., 2005). Gradual differences between breeds regarding udder health, as found in the multilevel regression model of SCS, have been previously demonstrated: Holstein cows were found to be more susceptible to mastitis than Jersey cows (Washburn et al., 2002), Swedish Red cows (Persson Waller et al., 2009), Brown Cattle, and Fleckvieh (Schwarzenbacher, 2001). Our findings of Fleckvieh having fewer udder health problems than Brown Cattle and, within Swiss Brown cattle, OB having fewer problems than BS also confirm previous findings (Schwarzenbacher, 2001; Wagner, 2006).

Furthermore, an effect of age of the herd in terms of average LN was shown with regard to \%Qmast and SCS. Many studies have found that older cows are at a higher risk of having mastitis and higher SCC (Bielfeldt et al., 2004; Ivemeyer et al., 2008; Breen et al., 2009). No further factors were predictors in more than one model.

In the multilevel analysis with regard to SCS, besides the already mentioned breed and LN, the number of new infections in $1 \mathrm{yr}$ and milk yield showed significant and plausible effects on cow differences. New infections implicate an increase of SCC (Schepers et al., 1997).
The association of lower milk yield with higher SCS is explainable due to cicatrization of udder histoids after mastitis infection combined with reduced milk production (Rajala-Schultz et al., 1999). The second factor among herds (with POS\% being the other), and the only management factor, was whether a radio was on during milking. Perhaps milkers who listen to the radio during milking are more relaxed, resulting in a more positive atmosphere during milking.

The only management factor remaining in the model for \%Qmast was DIM-LIE. Farms with lying places larger than standard dimensions had more mastitis quarters. A possible explanation might be that the risk of dirtying of cows and udders is higher with ample lying places, where cows are not forced to step back out of the cubicle before defecating. This parameter was also reported as a risk factor for subclinical mastitis in Doherr et al. (2007), but was in contrast to what Ivemeyer et al. (2009) found in tie stall and cubicle housing systems in univariate analysis only. Fregonesi and Leaver (2001) showed a higher risk of mastitis in straw-yard housing, which provides ample lying space compared with cubicle systems.

The strongest effect of management risk factors was found for the variable NEWINF with AIR-ADSORB and SEP-DIS. Additionally, as discussed above, the risk factor KICK, which was the only remaining factor from the area of the human-animal relationship in the NEWINF model, may be associated with milking hygiene. The factor SEP-DIS may contribute to lower NEWINF by preventing pathogens from spreading. However, it also possibly indicates an overall caring behavior of the stockpersons toward diseased animals, which may be combined with better management and increased attention toward their animals in general. Factor SEP-DIS was also found to have a preventive effect on clinical Escherichia coli mastitis (Barkema et al., 1999) and on average herd SCC (Mülleder and Waiblinger, 2004). Factor AIR-ADSORB was discussed above together with KICK and the higher susceptibility of HF cows.

\section{Model Fit and Study Design}

Fit of linear regression models $\left(\mathrm{R}^{2} \mathrm{adj}\right)$ ranged from $19.2 \%$ in the model for $\% \mathrm{Q}>100$ to $53.3 \%$ in the model for \%Qmast. Thus, model fit $\left(\mathrm{R}^{2}\right.$ adj) was in a similar range to that of comparable udder health studies (Waage et al., 2001; Jansen et al., 2009). The study design differs from some other epidemiological mastitis research projects (e.g., Busato et al., 2000) in terms of the investigated farms, which did not belong to a stratified random sample. Instead, preselected farms that had joined the pro-Q network were investigated, 
which indicated that the farmers were interested in the topic of udder health. This design helped to integrate and better mask the observation of behavior of milkers in the yearly farm data assessment within the pro-Q project. Despite the farmers' willingness to participate and their interest in udder health, the different parameters that were investigated varied largely. We would expect similar results regarding effects of the human-animal relationship in a random sample, but the required sample size to confirm effects statistically would most likely be larger. Methods for assessing the human-animal relationship were used and validated in previous studies and the observer in the present study was trained by previous users of these methods. Intraobserver repeatability of observing milkers' behavior was found to be $\mathrm{r}_{\mathrm{s}}=0.84$ (Waiblinger et al., 2002). Winckler et al. (2007) found a test-retest reliability between $\mathrm{r}_{\mathrm{s}}=0.76$ and 0.81 for cows' AD.

Udder health was described in 4 different ways, based on CSCS from milk recording data over $1 \mathrm{yr}$ and on quarter milk samples of all lactating cows. The variables differed in emphasis from more short-termed prevalence data $(\% \mathrm{Q}>100$ and \%Qmast on one given day of sampling) to more long-term (SCS and NEWINF) descriptions of herd udder health and from primarily SCC-based (SCS, \%Q>100) to more infection-reflecting (NEWINF, \%Qmast) characterizations. For calculating $\%$ Q $>100$ and \%Qmast, a threshold of 100,000 cells/mL was chosen as a physiologically normal SCC according to Hamann (2001). Nevertheless, a threshold of 200,000 cells/mL was chosen for defining new infections, because Dohoo and Leslie (1991) found that this higher threshold especially detected infections with major pathogens (Staphylococcus aureus, Streptococcus uberis, Streptococcus dysgalactiae, and coliforms). To calculate the new infection rate using CSCC was most feasible because no regular bacteriological milk samples over 1 yr were taken. We judged this method better than assessments of infections or clinical mastitis that depend on nonstandardized observations and estimations of the farmers. The CSCC-based new infection rate is also described by Valde et al. (2005) as suitable for describing herd udder health situations. The results support the choice of the parameters reflecting different aspects of udder health.

Epidemiological studies such as this cannot prove causality of a relationship. However, together with previous results from on-farm and experimental studies, our results strongly suggest a sequential relationship of human behavior toward the cows, cows' perception of humans and of interacting with them, and thus stress reactions and subsequent mastitis incidence. Nevertheless, the causality of these relationships needs be confirmed by further experimental studies.

\section{CONCLUSIONS}

The results confirm the multifactorial nature of mastitis, including cow characteristics and management factors as risk factors. Additionally, the results suggest that the human-animal relationship is relevant for udder health. Positive behavior of stockpersons during milking was associated with lower SCC and with lower prevalence of mastitis quarters. New infection incidence appeared to be less influenced by the human-animal relationship factors than by management factors. Consequently, the human-animal relationship, especially behavior during milking, may get more attention as one possible action point in extension programs for preventive mastitis control. Further research is needed concerning the efficiency of a preventive mastitis control program with integrated advisory activity regarding human-animal relationships.

\section{ACKNOWLEDGMENTS}

All farmers participating in the project are gratefully acknowledged for cooperation. COOP Sustainability Fund is acknowledged for financial support of the proQ project.

\section{REFERENCES}

Aeberhardt, K., R. Bruckmaier, and J. W. Blum. 1997. Hochleistungskühe in der Schweiz. Agrarforschung 4:277-280.

Barkema, H. W., Y. H. Schukken, T. J. Lam, M. L. Beiboer, G. Benedictus, and A. Brand. 1999. Management practices associated with the incidence rate of clinical mastitis. J. Dairy Sci. 82:1643-1654.

Barnett, J. L., P. H. Hemsworth, D. P. Hennessy, T. H. McCallum, and E. A. Newman. 1994. The effects of modifying the amount of human contact on behavioural, physiological and production responses of laying hens. Appl. Anim. Behav. Sci. 41:87-100.

Bielfeldt, J. C., R. Badertscher, K. H. Tölle, and J. Krieter. 2004. Factors influencing somatic cell score in Swiss dairy production systems. Schweiz. Arch. Tierheilkd. 146:555-560.

Breen, J. E., M. J. Green, and A. J. Bradley. 2009. Quarter and cow risk factors associated with the occurrence of clinical mastitis in dairy cows in the United Kingdom. J. Dairy Sci. 92:2551-2561.

Breuer, K., P. H. Hemsworth, J. L. Barnett, L. R. Matthews, and G. J. Coleman. 2000. Behavioural response to humans and the productivity of commercial dairy cows. Appl. Anim. Behav. Sci. 66:273-288

Breuer, K., P. H. Hemsworth, and G. J. Coleman. 2003. The effect of positive or negative handling on the behavioural and physiological responses of nonlactating heifers. Appl. Anim. Behav. Sci. $84: 3-22$.

Busato, A., P. Trachsel, M. Schällibaum, and J. W. Blum. 2000. Udder health and risk factors for subclinical mastitis in organic dairy farms in Switzerland. Prev. Vet. Med. 44:205-220.

Caroprese, M., F. Napolitano, M. Albenzio, G. Annicchiarico, M. Musto, and A. Sevi. 2006. Influence of gentling on lamb immune response and human-lamb interactions. Appl. Anim. Behav. Sci. 99:118-131.

Chassagne, M., J. Barnouin, and M. Le Guenic. 2005. Expert assessment study of milking and hygiene practices characterizing very low somatic cell score herds in France. J. Dairy Sci. 88:1909-1916.

De Passillé, A. M., and J. Rushen. 1999. Are you a source of stress or comfort for your cows? Adv. Dairy Technol. 11:347-360. 
Doherr, M. G., M. Roesch, W. Schaeren, M. Schällibaum, and J. W. Blum. 2007. Risk factors associated with subclinical mastitis in dairy cows on Swiss organic and conventional production system farms. Vet. Med. (Praha) 52:487-495.

Dohoo, I. R. 1993. An evaluation of the validity of individual cow somatic cell counts from cows in early lactation. Prev. Vet. Med. 16:103-110.

Dohoo, I. R., and K. E. Leslie. 1991. Evaluation of changes in somatic cell counts as indicators of new intramammary infections. Prev. Vet. Med. 10:225-237.

Dohoo, I. R., and A. H. Meek. 1982. Somatic cell counts in bovine milk. Can. Vet. J. 23:119-125.

DVG. 2002. Leitlinien zur Bekämpfung der Mastitis des Rindes als Bestandesproblem. J. Hamann and K. Fehlings, ed. Deutsche Veterinärmedizinische Gesellschaft, Fachgruppe "Milchhygiene", Sachverständigenausschuss "Subklinische Mastitis", Kiel, Germany.

Fregonesi, J. A., and J. D. Leaver. 2001. Behaviour, performance and health indicators of welfare for dairy cows housed in strawyard or cubicle systems. Livest. Prod. Sci. 68:205-216.

Goldstein, H. 1995. Multilevel Statistical Models. University of Bristol, Bristol, UK.

Gross, W. B., and P. B. Siegel. 1982. Socialization as a factor in resistance to infection, feed efficiency, and response to antigen in chickens. Am. J. Vet. Res. 43:2010-2012.

Hamann, J. 2001. Relationships between somatic cell count and milk composition. Pages 1-8 in Proceedings of the IDF World Summit. IDF, ed, Auckland, New Zealand.

Hamann, J. 2008. Zur Bekämpfung der bovinen Mastitis unter Praxisbedingungen. Tierarztl. Umsch. 63:643-650.

Harmon, R. J. 1994. Physiology of mastitis and factors affecting somatic cell counts. J. Dairy Sci. 77:2103-2112.

Hemsworth, P. H., J. L. Barnett, A. J. Tilbrook, and C. Hansen. 1989. The effects of handling by humans at calving and during milking on the behaviour and milk cortisol concentrations of primiparous dairy cows. Appl. Anim. Behav. Sci. 22:313-326.

Hemsworth, P. H., G. J. Coleman, J. L. Barnett, and S. Borg. 2000. Relationships between human-animal interactions and productivity of commercial dairy cows. J. Anim. Sci. 78:2821-2831.

Holtenius, K., K. Persson Waller, B. Essen-Gustavsson, P. Holtenius, and C. Hallen Sandgren. 2004. Metabolic parameters and blood leukocyte profiles in cows from herds with high or low mastitis incidence. Vet. J. 168:65-73.

Hüsler, J., and H. Zimmermann. 2006. Statistische Prinzipien für medizinische Projekte. Vol. 4. Verlag Hans Huber, Bern, Switzerland.

Ivemeyer, S., A. Maeschli, M. Walkenhorst, P. Klocke, F. Heil, S. Oser, and C. Notz. 2008. Effects of a two-year dairy herd health management programme on udder health, use of antibiotics and longevity. Schweiz. Arch. Tierheilkd. 150:499-505. (In German)

Ivemeyer, S., M. Walkenhorst, F. Heil, C. Notz, A. Maeschli, G. Butler, and P. Klocke. 2009. Management factors affecting udder health and effects of a one year extension program in organic dairy herds. Animal 3:1596-1604.

Jansen, J., B. H. van den Borne, R. J. Renes, G. van Schaik, T. J. Lam, and C. Leeuwis. 2009. Explaining mastitis incidence in Dutch dairy farming: The influence of farmers' attitudes and behaviour. Prev. Vet. Med. 92:210-223.

Knierim, U., and N. K. Waran. 1994. The influence of the human-animal interaction in the milking parlour on the behaviour, heart-rate and milk yield of dairy cows . Appl. Anim. Behav. Sci. 40:85-86.

Milne, M. H., A. M. Biggs, D. C. Barrett, F. J. Young, S. Doherty, G. T. Innocent, and J. L. Fitzpatrick. 2005. Treatment of persistent intramammary infections with Streptococcus uberis in dairy cows. Vet. Rec. 157:245-250.

Moberg, G. P. 2000. Biological response to stress: Implications for animal welfare. Pages 1-21 in Biology of Animal Stress. G. P. Moberg and J. A. Mench, ed. CAB International, Wallingford, UK.

Mülleder, C., and S. Waiblinger. 2004. Analyse der Einflussfaktoren auf Tiergerechtheit, Tiergesundheit und Leistung von Milchkühen im Boxenlaufstall in konventionellen und biologischen Betrieben unter besonderer Berücksichtigung der Mensch-Tier-Beziehung.
Endbericht zum Forschungsprojekt 1267. VUW Eigenverlag, Wien, Austria.

Munksgaard, L., A. M. De Passillé, J. Rushen, M. S. Herskin, and A. M. Kristensen. 2001. Dairy cows' fear of people: Social learning, milk yield and behaviour at milking. Appl. Anim. Behav. Sci. $73: 15-26$.

Persson Waller, K., B. Bengtsson, A. Lindberg, A. Nyman, and H. Ericsson Unnerstad. 2009. Incidence of mastitis and bacterial findings at clinical mastitis in Swedish primiparous cows - Influence of breed and stage of lactation. Vet. Microbiol. 134:89-94.

Rajala-Schultz, P. J., Y. T. Grohn, C. E. McCulloch, and C. L. Guard. 1999. Effects of clinical mastitis on milk yield in dairy cows. J. Dairy Sci. 82:1213-1220.

Reneau, J. K. 1986. Effective use of dairy herd improvement somatic cell counts in mastitis control. J. Dairy Sci. 69:1708-1720.

Roesch, M., M. G. Doherr, and J. W. Blum. 2005. Performance of dairy cows on Swiss farms with organic and integrated production. J. Dairy Sci. 88:2462-2475.

Rushen, J., A. M. De Passillé, and L. Munksgaard. 1999. Fear of people by cows and effects on milk yield, behavior, and heart rate at milking. J. Dairy Sci. 82:720-727.

Rushen, J., L. Munksgaard, P. G. Marnet, and A. M. De Passillé 2001. Human contact and the effects of acute stress on cows at milking. Appl. Anim. Behav. Sci. 73:1-14.

Sato, K., P. Bartlett, L. Alban, J. Agger, and H. Houe. 2008. Managerial and environmental determinants of clinical mastitis in Danish dairy herds. Acta Vet. Scand. 50:4

Schepers, A. J., T. J. Lam, Y. H. Schukken, J. B. Wilmink, and W. J. Hanekamp. 1997. Estimation of variance components for somatic cell counts to determine thresholds for uninfected quarters. J. Dairy Sci. 80:1833-1840.

Schmied, C., X. Boivin, S. Scala, and S. Waiblinger. 2010. Effect of previous stroking on reactions to a veterinary procedure: Behaviour and heart rate of dairy cows. Interact. Stud. 11:467-481.

Schmied, C., X. Boivin, and S. Waiblinger. 2008. Stroking different body regions of dairy cows: Effects on avoidance and approach behavior toward humans. J. Dairy Sci. 91:596-605.

Schwarzenbacher, H. 2001. Vergleich von biologischen mit konventionellen Milchviehbetrieben in Niederösterreich. MS Thesis. Universität für Bodenkultur, Wien, Austria.

Senft, B., and J. Neudecker. 1991. Abwehrmechanismen der bovinen Milchdrüse. Tierarztl. Prax. 19:357-363.

Stärk, K. D., C. Frei-Stäheli, P. P. Frei, D. U. Pfeiffer, J. Danuser, L. Audigé, J. Nicolet, M. Strasser, B. Gottstein, and U. Kihm. 1997. Häufigkeit und Kosten von Gesundheitsproblemen bei Schweizer Milchkühen und deren Kälbern (1993-1994). Schweiz. Arch. Tierheilkd. 139:343-353.

Uvnäs-Moberg, K., B. Johansson, B. Lupoli, and K. SvennerstenSjaunja. 2001. Oxytocin facilitates behavioural, metabolic and physiological adaptations during lactation. Appl. Anim. Behav. Sci. 72:225-234.

Valde, J. P., O. Osteras, and E. Simensen. 2005. Description of herd level criteria for good and poor udder health in Norwegian dairy cows. J. Dairy Sci. 88:86-92.

Waage, S., S. A. Odegaard, A. Lund, S. Brattgjerd, and T. Rothe. 2001. Case-control study of risk factors for clinical mastitis in postpartum dairy heifers. J. Dairy Sci. 84:392-399.

Wagner, S. 2006. Eignung von Original Braunvieh-Genetik im Vergleich zu Brown Swiss-Genetik für Biol.-Milchviehbetriebe. BSc Thesis. Schweizerische Hochschule für Landwirtschaft (SHL), Zollikofen, Switzerland.

Waiblinger, S., X. Boivin, V. Pedersen, M. V. Tosi, A. M. Janczak, E. K. Visser, and R. B. Jones. 2006. Assessing the human-animal relationship in farmed species: A critical review. Appl. Anim. Behav. Sci. 101:185-242.

Waiblinger, S., C. Menke, and G. Coleman. 2002. The relationship between attitudes, personal characteristics and behaviour of stockpeople and subsequent behaviour and production of dairy cows. Appl. Anim. Behav. Sci. 79:195-219. 
Waiblinger, S., C. Menke, and D. W. Fölsch. 2003. Influences on the avoidance and approach behaviour of dairy cows towards humans on 35 farms. Appl. Anim. Behav. Sci. 84:23-39.

Waiblinger, S., C. Menke, J. Korff, and A. Bucher. 2004. Previous handling and gentle interactions affect behaviour and heart rate of dairy cows during a veterinary procedure. Appl. Anim. Behav. Sci. 85:31-42.

Walkenhorst, M., J. Spranger, P. Klocke, and W. Schaeren. 2005. Risk factors contributing udder health depression during alpine summer pasturing in Swiss dairy herds. Pages 642-648 in Mastitis in Dairy Production. H. Hogeveen, ed. Wageningen Academic Publishers, Wageningen, the Netherlands.

Washburn, S. P. S. L. White, J. T. Green, and G. A. Benson. 2002 Reproduction, mastitis, and body condition of seasonally calved
Holstein and Jersey cows in confinement or pasture systems. J. Dairy Sci. 85:105-111.

Wegner, T. N., J. D. Schuh, F. E. Nelson, and G. H. Stott. 1976. Effect of stress on blood leucocyte and milk somatic cell counts in dairy cows. J. Dairy Sci. 59:949-956.

Wiggans, G. R., and G. E. Shook. 1987. A lactation measure of somatic cell count. J. Dairy Sci. 70:2666-2672.

Winckler, C., J. Brinkmann, and J. Glatz. 2007. Long-term consistency of selected animal-related welfare parameters in dairy farms. Anim. Welf. 16:197-199.

Windschnurer, I., C. Schmied, X. Boivin, and S. Waiblinger. 2008. Reliability and inter-test relationship of tests for on-farm assessment of dairy cows' relationship to humans. Appl. Anim. Behav. Sci. 114:37-53 